\title{
Is Ghana's Democracy Counterproductive to Development? Democratic Short-Termism and the Politics of Development Planning in Ghana
}

\author{
Martin Acheampong \\ Bamberg Graduate School of Social Sciences (BAGSS), University of Bamberg - Germany \\ Email: martin.acheampong@uni-bamberg.de
}

\begin{abstract}
Research on the bi-directional relationship between political regimes and economic development has increased tremendously since Lipset's (1959) seminal examination of the implications of economic development on political regimes. While some scholars oppose modernizationists who tie the prospects for democracy to economic growth, significant bodies of literature have argued that since democracies consistently outperform autocracies in growth and development indexes, democracy rather is a sine qua non for development. Others also highlight the counterproductive effect of democratic politics and judge it to be present-bias and unrepresentative of future interest. This article relooks at the conversation of whether the pursuit of long-term development policies is feasible under democracies, with an empirical focus on Ghana. Aside from its enviable democracy track record, Ghana is touted as the first country in the developing world to roll out a development plan. Using long term planning as a proxy for transformative development, I investigate how elected political elites in Ghana respond to the dilemma of choosing between winning the next election by pursuing voter-pleasing short-term policy goals, and embarking on long-term structural transformation with short-term electoral disadvantages. I argue that competitive elections and associational liberties affect the pursuit of long-term policy planning in Ghana. The incentive to implement or abandon long term plans is shaped by the rational calculations of the country's political elites in response to the short-term preferences of electorates.
\end{abstract}

Keywords: Democracy, Development planning, Present-bias, Elections, Associational liberties, Ghana

DOI: $10.7176 / \mathrm{DCS} / 12-2-01$

Publication date: February $28^{\text {th }} 2022$

\section{Introduction}

Debate on the implications of political regimes on economic development continues to dominate both theoretical and applied research in comparative politics. The extant literature has almost exhaustively explored, for instance, the consequence of democracy on development and vice versa (Boston, 2021; Acemoglu and Robinson, 2012; Przeworski and Limongi, 1993; Siegle et al, 2004) with its complex, divergent and unending causal linkages. Some scholars have argued, for instance, that democratically inclusive and pluralistic political settlements do not only propel economic prosperity (Acemoglu and Robinson, 2012) but more importantly, since democracies consistently outperform autocracies in growth and development indexes, democracy is a sine qua non for development (e.g., Siegle, et al. 2004). Beyond pointing to a direct causal relationship between democracy and economic development, pro-democracy theorizing often associates democracies with political stability, lower frequency of military coups and enhanced capacity for resolving political grievances non-violently (Dahl, 1989) - conditions necessary for economic growth.

While it is true that democracies positively correlate to development, it is also true that consensus is yet to be reached on the actual causal direction of this relationship as contrasting scholarship abound to the effect that democracy equally fundamentally possesses anti-growth effects due to its focus on consumption against investment (Huntington, 1968). Closely related to this stretch of argumentation is the assumed counterproductive upshot of democratic politics which is thought to be present-bias and unrepresentative of future interest (Iselin, 2012). Democracy is said to be anti-developmental since democratic political elites are often short-term planners, myopic and "systematically biased in favour of the present" (Thompson, 2005:246) - a character not often associated with economic transformation. The remarkable growth in countries like South Korea, Hong Kong, Singapore, Taiwan and Japan dubbed the East Asian Miracle (Stiglitz, 1996) has further complicated the relationship. This is especially so in the context of the developmental state literature's claim that long-term policies are inevitable for development (Amsden, 1992; Deyo, 1987; Zysman, 1983). Developmental state theorists have not only sought to attribute significant prospects for transformative development to government's intervention, long-term planning and good synergy between state and the private sector but more importantly, to the type of regime in existence (Haggard, 1990). In consequence, impressions have been created that a democratic political architecture is not supportive of long-term planning and economic transformation, and that in order to enjoy democracy, people have to wait until the institutionalization of material progress (Lipset 1959; Johnson 1982). 
In this article, I take the position that conversations on the relationship between democracy and development would be far from settled if two different, yet interrelated considerations are ignored. First is the recognition that theoretical discussions on this nexus would continuously exhibit multiple patterns of causality unless the discourse is appropriately contextualized. Second, there is the need to disaggregate the multifaceted concepts of development and democracy in order to observe specific causal patterns. Bearing this in mind, this article uses 'the pursuit of long-term policies' as a proxy for development (see Jacobs, 2011; World Bank, 2004) and 'elections and associational liberties' as proxies for democracy to investigate in the Ghanaian context, whether policies with long term developmental effects are feasible in democracies and under which conditions. In order to grasp the relevant issues necessary in answering the question, I disaggregate the question as follows: How do competitive elections and the presence and agitations of interest groups make Ghanaian democratic political elites either long or short term planners? The article proceeds as follows. The first part highlights the democracy-development background of Ghana. I would then present a brief conceptual discussion of democracy, development and long term planning. This is followed by a theoretical discussion on the motivations, behaviour and political choices of political actors. The next section empirically focuses on the nexus between democracy and long term planning in Ghana.

\section{A background to democracy and development in Ghana}

Ghana has long chalked an enviable record as an epitome of democracy and good governance and is celebrated as a model for stability and democracy in Africa (Gyimah-Boadi, 2009; Sithole, 2012). The institutionalization of democracy has, however, not been accompanied by economic success. Notwithstanding the country's attainment of a Middle-Income Country (MIC) status, perennial economic issues like wide gaps in infrastructural development, low productivity and weak overall human development exist (Nketia-Amponsah, 2015). The country for example is swallowed by high indebtedness, currently $81 \%$ of GDP with $48 \%$ youth unemployment (World Bank, 2020) and mostly affected by inflation and depreciation which in BTI's (2016) report reached a "dangerous level" in 2014.

Instead of pursuing radical poverty eradication programs and structurally transforming the economy, which is mainly agriculture, oil and recently service dependent, through long term policy planning and investment, the government's agenda to ensuring economic growth puts macroeconomic stability management through fiscal policies and taxation at the forefront (Killick and Malik, 1992). What is, however, clear is that Ghana's movement to sustainable growth and development with focus on manufacturing, wealth generation and employment creation may depend solely not on the usual macroeconomic stability management, heavy reliance on natural resources, Official Development Assistance (ODA) or the export of oil and agricultural commodities but rather on the pursuit of policies that fundamentally transform the structure of the economy. Both on the theoretical and policy fronts, there is a wide recognition that the country should consider restructuring the industrial and allied sectors while at the same time supporting the development of appropriate manufacturing technologies (Kwakye, 2012).

Beyond this, the removal of the many production bottlenecks in the already functioning industries through selective strengthening and rehabilitation should also be targeted (Ackah et al. 2014). In recognition of the fact that public policies that result in transformative social, economic and physical change require a great deal of long term planning (Jacobs, 2011), frequent calls on the Government of Ghana for long term policy planning have constantly been made. As a result, in 2015, a 40-year development plan starting from 2018 to 2057 was launched as the blueprint for national sustainable development and the framework to accelerate growth and reduce poverty. While the capacity of long-term plans to generate structural transformation of the economy of Ghana is not in doubt, opinions are mixed on the willingness of the Ghanaian political elite to implement them. The unpreparedness to pursue long term policies is usually blamed on the lack of implementation commitment on the part of the ruling elites (Ayisi, 2015).

However, any analysis of the disinclination of the Ghanaian politician to long term planning will be far from critical when only looked at on the individual level without analysing the structural impediments posed by the very political settlement in which the plans are to be operationalised. The issue, therefore, has to do with what is inherent in democracies that inhibit the pursuit of long term planning. As I shall show in this article, development plans are not new in Ghana and indeed have featured in the development agenda of almost all successive governments even before decolonization. Yet they have all failed to either arrest the problems they sought to correct or were entirely set aside or replaced. The reason why different governments in Ghana propose development plans yet shelve them in pursuit of policies that deliver quick, visible and immediate rewards is the subject that this article investigates. Before I take this point up, I start with a discussion on democracy and development. 


\section{Conceptual clarification}

\subsection{Democracy}

Comparative Politics is yet to clearly demarcate the theoretical boundaries of democracy to come to a consensus on a universal conceptualization. The term has controversially depicted different things to different people in different contexts. The Greek origin of the word; demos - construed as "full citizens"; and kratos, meaning "to rule" portrays the concept as a type of rule by many, opposed to rule by a few (Göbel and Leininger, 2012; Coppedge and Gerring, 2011). This conceptualization promises no solution to the conceptual confusion around the term especially when viewed in its modern representative form. Often, differing, conceptually contradictory adjectives ranging from participatory, liberal, electoral, deliberative, majoritarian, pluralist to egalitarian (Coppedge and Gerring, 2011) have emerged to define the concept. Although attempts have been made to integrate these multiple theories and concepts into meta-theories or meta-concepts, the obviously incongruous character of these integrated theories goes to underscore how complicated it is to be conceptually precise on what democracy is (Campbell, 2009). One can, however, observe a common alignment in understanding the variants of democracy by looking at it through the minimalist and maximalist spectacles.

The minimalists associate democracy with the institutional arrangement of holding periodic free and fair elections, human rights guarantee and universal adult suffrage (Bühlmann et al. 2007). Democracy is a means of protection against the arbitrariness of rulers. Noteworthy, however, is that the protection of citizens from abuse does not usually come at the will of rulers but only ensured when the filling of the office of the ruling elites is subjected to competition. Hence, what assumes centrality in the minimalist conception of democracy is election. The principal proponent of the minimalist notion of democracy is Joseph Schumpeter (2003). He looks at democracy as an established procedure in which the power to take decisions on behalf of a group of people is acquired by a competitive struggle for the votes of the people. More succinctly, he sees democracy as an "institutional arrangement for arriving at political decisions in which individuals acquire the power to decide by means of a competitive struggle for the people's vote" (Schumpeter, 2003:269). This thinking is a fundamental departure from the orthodox and normative conceptualizations that emphasize on inter alia equal opportunities and freedoms and not merely the institutional mechanisms of producing governments. Democracy in the minimalist perspective places full premium on elections which serve as the mechanism for aggregating people's interest without which the people remain passive political participants.

Przeworski (1999) did not only provide an endorsement to the minimalist conceptualization and the primacy of electoral competition in democracy theorizing but more importantly, he deemed it as a value in itself. He sees democracy as a system in which there is rule-based competition with periodic winners and losers. Hence the essence of democracy in Przeworski's perspective is the peaceful transfer of political power through a duly instituted electoral mechanism. The minimalist conception of democracy is hailed for its simplicity which makes it strong, focused and flexible. Unlike the many conceptualizations of democracy that simultaneously go too far in their classifications with application difficulties, the minimalist theory is direct and specific.

The maximalists on the other hand see democracy beyond the minimum standards of electoralism to multidimensionally rake in tenets like political freedoms and civil liberties, civic participation and socio-economic equality. Liberal democratic theorizing, which I classify under maximalism, arises in opposition to the minimalists' association of democracy to electoral competition. Maximalism is founded on the premise that focusing only on elections as a determiner of democracy fundamentally overlooks several crucial aspects of a functional democracy. Levitsky and Way (2002) for instance bring attention to the many "competitive authoritarian" regimes that periodically hold free and fair elections yet trample on other aspects of democracy like free speech, civic and political liberties, judicial independence inter alia. Dahl (2000) therefore outlines seven institutional guarantees including elected officials; free and fair elections; inclusive suffrage; right to run for office; freedom of expression; alternative information and associational autonomy (Dahl 2000) as primary benchmarks to determine democracies. Diamond (1999) adds that for the individual and group's liberty to be adequately protected and insulated from state control, institutions ranging from the constitution to independent judiciary and parliament, civil society, and independent media must be guaranteed. Hence the foundation of democracy according to Dahl and Diamond is government's responsiveness to the preferences of its citizens and their treatment as equal citizens.

Even though this conception is broader compared to the minimalist's and covers the essential components of democracy, it has been critiqued as having too many properties making its wholesome attainment as difficult as impossible. I notwithstanding rely on it in my analysis of Ghana's democracy since a restriction to the minimalists' electoral fundamentalism leaves many important branches of democracy out of the analysis. Again since the procedural and electoral components of the minimalist approach constitute a subset of the maximalist theorizing, a reliance on the latter is most appropriate. The maximalist conception therefore provides a broad, multi-dimensional approach to conceptualizing democracy. I would be concentrating on two tenets of the maximalist democracy, namely competitive elections and associational liberties for my analysis. 


\subsection{Development}

The context driven and diverse nature of development make its conceptualization equally difficult. The simplest and popular connotation has been the advancement from a current state to a higher one. Simple as this definition may sound, one can connect it to alternative concepts like improvement, wellbeing, progress and economic or human growth. The multiple ways of construing development therefore leads to the conclusion that there is no such thing as a definitional certainty. I explore two basic approaches of development in an attempt to understand the concept and to highlight its relevance to this article.

First, the economic growth understanding of development is one of the orthodox schools likening development to sustained growth in the income per capita of a state at a much faster rate than its population growth. The core argument here is that an increment in a nation's net wealth coupled with industrialization enhances its potential for poverty reduction and also aids in the solution of its societal problems. As Deininger and Squire (1996) contend, growth affects poverty reduction. This translates to mean that the more a country experiences economic growth, the richer its citizens become. They argue that, in the same way growth tremendously benefits the poor in the vast majority of cases, economic decline also often disproportionately hurts the poor. In essence, households' propensity, for instance, to spend their income as a result of economic growth on such items as food, portable water, good health and education directly translates into development. Fields (1989) comes to a similar conclusion in his investigation of the relationship between growth, poverty and inequality. Using headcount ratio and inequality by the Lorenz curve and GINI coefficient to measure poverty, he concluded that economic growth has a positive implication on development. As Ranis et al (2000) observe, most development interventions and expenditure in developing countries have concentrated on increasing income levels with the understanding that poor households increase their expenditure on food and calorie consumption when they receive extra income. Development therefore is seen as a product of fat GNP or rise in personal income levels or massive industrialization and social reforms.

This conceptualization of development is not only desirable relative to its easy measurability but also adopts a straightforward understanding of the impact of incomes on development. For example, the notion that increment in incomes available to households and governments affect the range of choices and capabilities they enjoy and consequently enhance development brings to the fore the core essence of human development. While acknowledging the simplicity of this approach and admitting that assigning many different definitional components to development makes it subjective, a substantial body of scholarship critique this logic and indicate that the extent of poverty reduction as a result of growth does not depend on the level of the growth per se but the rate of distribution (Sen, 1999). Bruno et al (1995) for instance, find that whether or not economic growth leads to development depends on how employment, redistribution and rural poverty are affected by this growth. They argue that in some cases, economic growth actually is associated with an increment in the population of the poor if redistribution is not prioritised.

Sen (1999) contends that development cannot be reduced in simple terms to refer to an increment in basic incomes or rising income per capita. He critiques the growth-development understanding by asking whether certain social and political freedoms like the liberty to participate and dissent politically, right to education, right to receive quality health care cannot qualify to constitute a component of development. Sen therefore sees development as freedoms (Sen, 1999). He argues that freedom is not only primary but also a principal means of development. He advances an expanded understanding of freedoms to include five categories namely economic empowerment, political freedoms, social opportunities, protective security and transparency guarantees. The principal strength of this conceptualisation is the broad way in which development is conceived. Aside accommodating the economic growth and GNI understanding, Sen's approach associates development with the removal of all forms of tyranny and deprivation as well as the guarantee of economic opportunities. Sen argues that the different types of freedoms; be it economic, social or political complement and reinforce each other in defining development.

\subsection{Long term development planning}

First of all, what does "long term" mean and what specific timeframe qualifies to be deemed a long term? As Boston (2014) contends, long term implies an extended or lengthy-time timeframe; depending on a specific policy context, it could usually be years, decades or even longer. This means that a policy or plan could only have a long term character when it extends over years but the specific time horizon depends on the particular policy, its purpose the degree of work involved in its achievement and so on. Sprinz (2009) on his part holds that long term policies could even last for generations. He sees long term policies as the type of policies "that last at least one human generation, exhibit deep uncertainty exacerbated by the depth of time, and engender public goods aspects both at the stage of problem generation as well as at the response stage" (Sprinz, 2009:2). From this perspective, one can distil some features of long term policies. First, Sprinz argues that long term policies last a generation of 25 years. The time period of 25 years could be the minimum number of years to qualify a plan or policy to be labelled a long term in Sprinz's calculation but could equally be lesser or more depending on 
the nature of the problem the policy is to correct and the context as Boston (2014) indicates. The second feature of long term policy is uncertainty. As he argues, depending on the number of years involved in long term planning and its forward-looking character, long term policies are usually characterized by deep uncertainty. This feature is further exacerbated by possible inaccuracies in predicting the future of a half century policy, for instance.

Iselin (2012) on his part departs from Sprinz on his view on the time horizon of a long term. He argues that a period is long enough when "either the problem or solution proposed will take at least one generation (roughly 30 years) to fully materialize" (Iselin, 2012:4). Boston and Pebble (2013) also see a long term plan as one that covers a period of 40 years. These positions, at least, bring to the fore the understanding that the actual timeframe required for a plan or policy to be deemed "long term" is contentious and could mean any period from 25 years (Sprinz, 2009) to 30 years (Iselin, 2012) or 40 years (Boston and Pebble, 2013). Beyond the lack of consensus on the actual time horizon, scholars generally agree that a long term plan is formulated with the future generation in mind with anticipated short term costs (Sprinz, 2009; Iselin, 2012; Boston and Pebble, 2013). This leads to the core definition that a long term plan is a design that takes into account and represents the future generation. Long term therefore should not be only conceived in terms of the timeframe or the number of years a plan or policy covers but rather whether or not the policy has the future generation in mind. Thus a long term policy constitutes an investment into the future of the next generation with short term social costs. Long term plan is therefore a policy strategy, intervention or investment which aids in the creation of a better future by first deferring immediate gains for the pursuit of a lasting and enduring improvement in the lives of a people.

\section{Theoretical framework: The theory of intertemporal policy choices}

The theory of intertemporal policy choice constitutes the background of this article. It helps in deducing the motivational, behavioural and political choices of political actors in the midst of short term electoral imperatives and organized groups agitations. Jacobs (2011) proposed this model by asking the question; "under what conditions do democratic governments enact policies that impose costs on constituents in the short run in order to produce long term social gains"? This question invariably brings out the problem of timing which he argues is the thorniest fix governments usually find themselves. Thus, "when" to distribute "which" public goods constitutes one serious dilemma for politicians especially when determining policy choices involving trade-offs between short-term, immediate benefits and long-term policies with deferred consequences - this is what he calls intertemporal dilemmas in making policy choices. The core of the problem, however, is the essence of time and the fact that public policies that result in transformative social, economic and physical change require a great deal of long term planning. How, therefore, does the typical elected politician respond to such a predicament to plan for [desirable] long term against short term? Like Iselin (2012), Mank (1996) and Thompson (2005) who argue that democratically elected politicians lack the motivation to pursue long term policies, Jacob's puzzle is a reflection and admission of such a fix with democratic elites. Thus, while politicians desirous of remaining in office often attend to the immediate needs of their constituents by trading off the future in favour of short-term benefits, others do, of course, attend to the needs of the next generation in their policy choices. The question is, why would elected politicians impose short-term costs on voters to jeopardise their electoral chances in favour of long term gains? I argue that the intertemporal choices of elected politicians are determined by three conditions; (1) the degree of electoral comfort they enjoy, (2) the expected long-term social returns of the policies they pursue and (3) the institutional capacity at their disposal.

\subsection{Electoral safety}

I start by assuming that politicians have one primary aim: to stay in office (Mayhew, 1974). This is due to the benefits public office holding provides, including unparalleled opportunities and the possibility to pursue the development of a country on the basis of one's own conception of society. Democratic politicians, therefore, stop at nothing in protecting their grips on power. This invariably means staying electorally appealing all the time to win the mandate of voters. In situations of fiercely competitive elections, the choices of elected politicians are determined by the immediate demands of the electorates. Hence, politicians tend to be constrained in their choices of policies in order to satisfy voters by awarding short-term policies. Beyond voters, the elected politician has to bow to the pressure and interests of organised groupings in the state if she is to win the next elections. Therefore, succumbing to voter and group pleasing programs in a competitive electoral environment in order to be electorally appealing provides a powerful counterweight to the pursuit of long term policies. In consequence, for democratic politicians to invest in long term policies, they must enjoy an appreciable electoral safety or even be insulated from competitive political forces and face a lower risk of electoral defeat as a result of imposing short term costs in favour of long term investment.

\subsection{Long term social returns}

The second condition for intertemporal policy choice is the expected long term social returns. For democratic 
politicians to embark on long-term investment as opposed to short-term policies, there must be an understanding or a consensus among the political elites that the proposed policy investment will deliver substantial net longterm social returns. Beyond this, there should be an agreement and assurance that the outlined policy can withstand any risks of future failure. Boston (2014) adds that due to the fact that a particular policy could be designed to potentially favour one party or the other in the long run, the concerned elites must be satisfied with the potential of the policy to reduce opportunism in the future.

\subsection{Institutional capacity}

The third condition for long term investment is the possession by the political elites the institutional capacity to enact their long term policies into enforceable laws. This capacity usually suffers institutional constraints from organized interest groups that seek to persuade and, in most cases, pressurize policy making in their favour. The prominent space social groups enjoy in democracies usually feed them with extraordinary lobbying prowess to affect policy decisions to their advantage or even sometimes succeed in forcing a referendum. Due to the fact that organized groups usually have specific interests, they are often at the receiving ends of short term costs as a result of the pursuit of long term policies. Hence the high stakes of concentrated interest groups like unionised workers in intertemporal policy choice cannot be underestimated. Thus, society is likely not to benefit from long term policy investment if one of these conditions - electoral safety, expected long term social returns and institutional capacity are not met.

\section{The state of democracy and development in Ghana}

A confluence of both international and domestic factors drove Ghana's transition to democracy in 1993. Ninsin (1998) recalls the pro-democracy trend that emerged after the collapse of the Soviet Union and how it contagiously affected African regimes. Ghana participated in this changeover to political liberation that swept throughout the globe referred to by Huntington (1993) as the Third Wave of Democratization. The country's accelerated democratization also owes to the greater emphasis of donor governments on political reforms in the south which in the late 1980s became an important conditionality for continued financial and technical support. Domestically, the PNDC faced tremendous pressure from civil society organizations notable among them were the Ghana Bar Association (GBA), National Union of Ghana Students (NUGS) and the Christian Council of Ghana (CCG) to return the country to civilian rule. Due to its poor human rights records and fears over the uncertainties that could characterize its surrender of power, the PNDC initially was resistant to the reforms (Gyimah-Boadi, 1991) but later softened its stance and deliberately, carefully drove the transition process to its political and legal advantage (Frempong, 2008).

In 1992, the long ban on political parties was lifted, leading to the formation of such political parties as the New Patriotic Party (NPP), the People's National Convention (PNC), the Peoples' Heritage Party (PHP), National Convention Party (NCP) and the National Independence Party (NIP). The leader of the PNDC, Jerry Rawlings, did not only form the National Democratic Congress (NDC) to contest the maiden presidential and parliamentary election but also tilted the political environment to his advantage (Oquaye, 2004). Quite characteristic of most transition elections, the 1992 elections were not without its share of acrimonies (GyimahBoadi, 1999). The opposition raised red flags over the fairness of the Election Management Body (Ninsin 2006), alleged of systematic rigging of the polls (Oquaye, 2004), complained of government-instigated violence and intimidation (Amankwaah, 2013) and so on. They consequently boycotted the parliamentary elections after they lost the presidential polls. Even though the transition was described largely as a "transition without change" (Gyimah-Boadi, 2008:4) due to the fact the democratic constitution had been designed to retain some of the autocratic elements of the previous military rule and also featured a clear lack of distinction in terms of personnel and portfolio between the erstwhile military regime and the democratic regime, many argue that the mere opening of the political space paved the way for remarkable democratic development.

Specific instances of democratic development, according to Gyimah-Boadi (2008) include the improvement and enjoyment of basic human rights, freedom of operation for the opposition parties, free civil society activism, substantially relaxed media censorship. Evidence from democracy indexes such as the Freedom House's Freedom in the World survey provides ample support for the country's high democratic achievement. Although the country started from a humble beginning (partly free) in 1992, it rose through the years to attain a "free" status beginning from 2000 to date. Thus, unlike the many African democracies that have suffered breakdowns or stagnation as a result of conflictive elections (Cheeseman, 2015), Ghana has organized eight reasonably peaceful multi-party elections with two political parties alternating power. Even in the most competitive of elections, such as the 2008 Presidential election which was won by the then opposition NDC by a margin of less than $0.5 \%$, power was peacefully transferred. Such a scenario could have easily degenerated into a catastrophe had it not been the democratic maturity of Ghana, thus giving the country the accolade of a trailblazer of peaceful transitions of power in Africa (Sithole, 2012). Large consensus thus exists that Ghana's election is unparalleled in Africa in terms of quality and acceptance (Sithole, 2012; Gyimah-Boadi and Prempeh, 2012). 
On the front of development, Ghana's growth has been remarkable. The country has travailed successfully from a period of turbulent economic hardship in 1970s and 1980s to the current era of steady economic growth and human development. Although Ghana's growth has been remarkable over time, little attendant transformation in the structure of the economy has been witnessed (Killick, 2010). The main preoccupation of the PNDC administration in the 1980s was macroeconomic stability management and the improvement of the state of the Ghanaian economy mainly with inflows from development aid (Killick and Malik, 1992). The economic policy in the subsequent years has not departed fundamentally from measures aimed at infusing fiscal sanity to the exchange rate and fiscal budget control, leading to the acceleration of growth especially in the 1990s and progressively between 2000 and 2014 (Osei et al. 2015). However the structure of the economy remains unchanged throughout the period. This is what Kwakye (2012) refers to as the "Guggisberg economy" to describe the cocoa, gold, import and aid-dependent nature of the Ghanaian economy.

Agriculture, for instance, has remained the main contributor to Ghana's GDP from the 1960s until it was taken over by the services sector in 2006 (Osei et al, 2015). One would typically argue that the movement from an "agricultural economy" to a "service sector" economy itself represents a change in the structure of the economy. While this is true, it is also true that this change is not transformative. Transformation occurs when a state transitions from an agriculture economy to a manufacturing one (Jedwab and Osei 2012). Models of structural transformation distinguish between labour push approaches which signify a rise in agriculture and labour pull approaches like a rise in non-agricultural productivity and industrial revolution (Harris and Todaro, 1970). On a continuum therefore, a developing country transitions from stages beginning with a decline in the contribution of agriculture to GDP, through manufacturing boom to the service sector in order to be economically developed. Ghana however skipped the manufacturing stage of development and leapfrogged to the service stage. The stagnation of the manufacturing sector and the lack of structural transformation for more than half a century after independence is the cause of the unprecedented unemployment, high cost of living and the weak Ghanaian currency (Kwakye, 2012).

\section{Long term policy planning in Ghana}

Ghana is the first country in the developing world to complete a development plan (Tandoh-Offin, 2013). The country's resort to long term development planning dates back to almost a hundred years when the then governor of the Gold Coast [as Ghana then was] Gordon Guggisberg realising the need to diversify the monocrop economy of the country, rolled out a 10 year development plan in 1920 - 1930 (Ewusi, 1973). The plan recognised the need for long term investment across different sectors of the economy especially in the transport and health sectors which received about $75 \%$ of the total budget for the plan (Kay 1972). Although the plan was abandoned in 1927 due to the reassignment of Guggisberg to British Guyana, its impacts are monumental even up to date. The Guggisberg plan resulted in the construction of the Korle Bu Hospital (Huq, 1989) which today is the largest referral hospital in Ghana (Der et al, 2013). Other infrastructural developments accomplished by this plan include the Akim Tafo to Kumasi railway line, the Tarkoradi Harbour and the Prince of Wales School, now Achimota College.

The collapse of the Guggisberg plan saw the putting together of another 10 year development plan (19461956) christened the Plan of Development and Welfare of the Gold Coast. This plan was only implemented in 1946 until a third major attempt at development planning dubbed the Economic and Social Development of the Gold Coast (1951-1961) was implemented (Ewusi, 1973). In 1951, when Ghana gained internal self-government, the Convention People's Party (CPP) led by Kwame Nkrumah collapsed the plan into a 5 year development plan as a result of the development exigencies of the time. Nkrumah rolled out the second part of the 5 year development plan in 1958 to cover the period 1959-1964 but was also terminated in 1961 and replaced by a 7 year Development Plan for National Reconstruction and Development (1963/64-1969/70). This plan budgeted at some $£ 1$ million has been the most comprehensive national development yet (NDPC, n.d) and recorded many accomplishments like the Kumasi Jute factory, the Akosombo Hydroelectricity plant, the Tumu Shea butter oil factory among many others. The plan was terminated after the 1966 coup that ousted Nkrumah's administration. Ghana then slipped into a long period of short term plans; the Two-Year Development Plan 1968-69-1969/70, the One-Year Development Plan July 1970-June 1971, the Five Year Development Plan 1975/76-1979/80 and the Economic Recovery Program 1984-1986. These plans were frequently undermined by the political turmoil and frequent changes in governments in the 1970s resulting in a terrible economic downturn. The 1980s therefore were characterised by short term macro-economic stability management to prepare the grounds for later economic revival under the World Bank/IMF Economic Recovery Structural Adjustment Programs (ERP/SAP). The return to democracy in 1993 once again saw Ghana's resuscitated interest in long term planning.

With the success of the ERP/SAP and the realisation that to ensure sustainable development, the country should return to long term policy planning, the return to democracy was accompanied with the creation of the National Development Planning Commission (NDPC) under Articles 86 and 87 of the 1992 Constitution. The 
NDPC was tasked to "within two years after assuming office, present to parliament a coordinated programme of economic and social development policies, including agricultural and industrial programmes at all levels and in all the regions of Ghana". Such plans are to give to the nation a blueprint for national progress and to institute a system of purposive discipline.

In 1995, the President presented to Parliament the first long term plan under the 4th republic; Vision 2020 The National Development Policy Framework (NDPF) and the Co-ordinated Programme of Economic and Social Development Policies (CPESDP) with the broad aim of transforming Ghana, achieving a balanced economy and raising the country to the level of development close to that of Singapore within twenty-five years between 1996-2020 with the first step in 1996-2000 (Osei-Bonsu, 2012). The plan was based on the following five thematic areas; human development, economic growth, rural development, urban development and enabling environment. In spite of the ambitious and achievable nature and the initial signs of promise the plan showed, it was set aside or "shelved and forgotten" Osei-Bonsu (2012) when there was a change in government in 2001 (NDPC, n.d). It must be noted that the NDC government which was in power from 1992 was voted out in the general 2000 elections. The NPP led by John Kuffour was elected to the presidency. Kuffour's government in the early days of its assumption of office replaced the vision 2020 with the Ghana Poverty Reduction Strategy (GPRS I; 2002-2005) and later the Growth and Poverty Reduction Strategy (GPRS II, 2006-2009), citing persistent and wide disparities between the planned targets of the vision 2020 and actual performance (NDPC, n.d).

The GPRS I\&II were mainly premised on poverty reduction, employment creation and human development. To be sure, Ghana's democratic architecture requires the holding of elections in every four years. Hence, the 2000 election was followed by the 2004 and 2008 elections, which saw the opposition NDC winning the presidential polls again and taking over the reins of government from the NPP in 2008. The new NDC administration led by John Atta Mills also followed "precedent" by setting aside the GPRS II of the previous government and replacing it with the Ghana Shared Growth and Development Agenda: 2010-2013 (GSGDA I), which was followed by the Ghana Shared Growth and Development Agenda: 2014-2017 (GSGDA II) (NDPC, nd).

The lack of implementation of development plans by successive governments has been blamed for the developmental stagnation of Ghana. The NDPC (nd:6) remarks that the public itself "has taken note of the ease and frequency with which successive governments set aside existing plans and replaced them with their own, without due regard for the implications of their actions for continuity in the national development process". The question of what causes this incessant practice of abandonment has engaged the attention of Ghanaian policy planners over the years. One dominant antidote suggested is to scrap the large discretion of the government to either implement or ignore existing plans and thus legally compel all governments to embrace long term plans (GNA, 2015). In this regard, calls were made to the Constitution Review Committee (CRC) in 2010/2011 to include provisions in the constitution to bind all successive governments to implement long term national development plans. Hence in their final report submitted to the government in 2011, the CRC dedicated a full chapter titled "From a Political to a Developmental Constitution" to development planning to show how seriously the issue of legal obligation to implement plans has been taken.

The recently outdoored 40-year development plan which will span from 2018 to 2057, when Ghana will mark its 100 years independence anniversary, has been said to possess some legal backing in contrast to the preceding plans. In fact in his response to public fears that this new plan would not survive political alternations, the Director-General of the NDPC; Nii Moi Thompson deflated public fears by warning that "governments which renege in implementing the plan will be sanctioned" (GNA, 2015). He indicates that a law has been submitted to the Parliament to ensure that the plan is legally binding and not made to perish with nonimplementation. Contrasting opinions have it that, putting legal imperatives on governments to implement existing plans - which they may not believe in - is not sufficient in making them implement it. As Awal (2015) contends, all a government that does not believe in the plan has to do is to repeal the law compelling its implementation in the next parliament to pave the way for the implementation of their electoral promises - a scenario which is highly possible since ruling governments usually win majority of the parliamentarian seats. Hence, why successive governments in Ghana sacrifice holistic transformative development plans for quick fixes, visible projects and prioritise the fulfilment of short term electoral promises cannot be explained by the lack of restrictive legislations but rather the very political system in which the plans function. The next section diagnoses why Ghana's democratic political settlement frustrates the implementation of long term plans.

\section{Is democracy anti-long term development? An explanation of policy trade-offs in Ghana's democracy}

It is important to begin by rejecting a dominant position in the literature on democracy and long term planning which argues that democracies are blinded by "presentism", conscious of consumption and systematically underrepresent the future. By this logic, politicians determinedly mortgage long term transformative investments that award immediate costs to their constituents for short term visible, immediately-satisfying fixes that do not 
go beyond the next election. I have supplied broad empirical evidence to show that Ghanaian politicians across the political spectrum generally recognise the need for long term planning; the issue rather is the lack of implementation. I argue that the implementation or otherwise of long term plans in a democracy is a result of the rational calculations by the political elites in response to the preferences of the electorates. To appreciate the relationship between democracy and long term development therefore, this section takes two very important features of democracy - election and associational liberties - and shows the extent to which they affect the implementation of long term plans and development in general.

\subsection{Competitive elections and the pursuit of long term development}

Nothing perhaps characterises democracies more than the competitive struggle for people's votes. Politicians, therefore, are usually preoccupied with what would constantly make them electorally appealing in the eyes of the voter and therefore tend to be distributive in order to win the next elections. This puzzle is equally true with the voter. The voter's decision on who to vote for is usually equally calculative and not simply arrived at. Note that, given shorter decision-making limits and the impossibility to be fully informed on all facets of electoral manifestoes (Jacobs, 2011), voters usually adopt what Iselin (2012) calls a mental shortcut in arriving at their voting decision. This has to do with a simple self-examination of whether they are better off today than the commencement of the electoral term. This simple mental judgement of the incumbent by electorates demonstrates that the average voter bases their voting decision on the short-term records of political parties. In a competitive electoral setting therefore, democratic politicians react to such mental assessments of the electorates by enacting and concentrating on visible, short-sighted policies. It is therefore understandable why they abandon long term plans and rather maximize near-term benefits.

It is in this context that I explain the frequent shelving of Ghana's long term development plans. We realised that the $4^{\text {th }}$ Republic of Ghana has fashioned out a competitive bi-party democracy with the NDC and the NPP as the frontrunners. Whitfield (2009) adds that these two parties possess near equal electoral strength and have alternated power since (re)democratization in 1992. The NDC, for example, won the 1992 and 1996 elections, while the NPP carried the day in 2000 and 2004. The following 2008 and 2012 elections were won by the NDC again while the 2016 and 2020 polls went for the NPP. I cannot skip attending to the extremely competitive nature of these elections, especially in 2008 where the opposition NDC won the run-off election against the incumbent NPP with less than 40,000 votes constituting less than a half percentage point.

This insight into Ghana's elections is to set the background to appreciating the intertemporal policy choices the typical elected Ghanaian politician makes. Political elites usually trade off long term investments and shelve long term plans as a consequence of the impediments of the ever-present electoral myopia. Situating the calculative nature of voters and their model of performance assessment into the competitive electoral culture of Ghana, one realises that a typical politician desirous of winning elections would lack the motivation to associate with long term policies. The NDC government's vision 2020, for example, was set aside by the NPP upon winning power in 2000 for the implementation of its near-term development interventions that align to the government's own goals (Stănculescu, 2003) since continuity of the NDC's long term vision with the obvious short term costs would present it with a huge electoral risk in the subsequent elections. The NPP also introduced many long term projects under the GSGDA I\&II like the popular affordable housing project but was equally abandoned by the NDC when it won the 2008 elections. There are several other examples of policy discontinuity like the botched decongestion exercises, the counter policies on the duration of Senior High School, the 1999 Comprehensive Youth Policy etc. (Gyampo, 2012). This culture of long term policy discontinuity in Ghana happens when the pursuit of the long term interest clashes with short term electoral fortunes of the ruling elites. Since policies that result in remarkable development require long term planning (Jacobs, 2011), their abandonment due to the dictates of democratic politics retards national development (Gyampo, 2015).

In my analysis of the relevance of long term planning for development, I relied on the Commission on Growth and Development's report (World Bank, 2004) which cited Botswana [also a democracy] as a success case for development planning in Africa. Patterson (2006) on his part did not only commend the successful long term plans of the country, but also recommended it for other African countries. I argue that such generalised recommendations need to be appropriately contextualised. To make such recommendation, one has to interrogate the differences in the political settlements and electoral politics of the countries under consideration. Unlike Ghana, for instance, Botswana's political space is dominated by a de facto one party - the Botswana Democratic Party (BDP) - which has won all general elections since the country's attainment of nationhood in 1966 (Sebudubudu and Osei-Hwedie 2006). Hence this electoral safety and near insulation from political change that the BDP enjoys gives it the comfort to implement its long term plans. As Jacobs argues, the only condition under which a [democratic] government implements its long term plans is when they "face a relatively low risk of losing office as a consequence of imposing investment's short-term costs on voters" (p.29). In this regard, where voters have more than one equally compelling alternative, it is difficult to avoid the influence of mental shortcuts. This is simply human nature and the elected politician knowing this, mortgage long term issues for the present as 
in the case of Ghana.

I do not argue that voters do not appreciate long term policies. Indeed Ghanaians are increasingly becoming indignant about political elites' penchant to truncate long term oriented policy plans of previous governments (see NDPC, n.d). However, this is to say that in deciding on whom to vote for, voters rely on tangible and concrete policies and projects they can point at in the incumbent's previous term as an evaluative yardstick to judge the ruling elites. Since long term policies may take years or even generations to deliver, there will hardly be anything tangible of a record to show for in a 4 year term. The retrospective way of voter assessment in competitive electoral democracies provides incentives against long term policies. Therefore pursuing long term policies in Ghana's highly competitive democratic political system unpopularises and jeopardizes a government's future electoral chances due to the retrospective voting character of voters. In this case, democracy may negatively affect development.

\subsection{Organized groups' agitations and the implementation of long term plans}

The return to democratic rule in 1993 was accompanied with the guarantee of wide associational rights in Ghana. The number of registered Civil Society Organizations (CSOs), NGOs and Community Based Organization (CBOs) rose from less than 80 in the 1980s to 652 in 1996 to 1211 in 2000 (Abdulai and Quantson, 2008) and to 6,258 in 2014, not to talk of the spontaneous ones that emerge as and when issues of interest pop up. CSOs in Ghana have increasingly influenced and impacted government policies using several strategies like boycotts, strikes, advocacy and the initiation of bills (Gyimah-Boadi, 2010). The Institute of Economic Affairs (IEA), for instance, is credited with the initiation of the Presidential Transition Bill (2012) passed by the Parliament of Ghana in 2012 after amalgamating the reports of its observation of the 2008 general elections with previous ones. Again, the passage of the Petroleum Revenue Management Law by Parliament was as a result of the constant lobbying by CSOs. Beyond legislations, the realisation and recognition of organised groups as formidable development partners have seen many important contributions, pressures, lobbying and the influencing of many government policies. I should cite an example here; the establishment of the University of Education to train professional teachers, the divorce of the Ghana Education Service from the Civil Service and the policy to create kindergarten as a separate pre-school system from the mainstream school structure were all the result of constant advocacy by the Ghana National Association of Teachers (GNAT) (CIVICUS, 2013).

Underline that organised groups pursue specific issues in line with their interest and areas of focus and hence either support or reject policies that directly affect their members such as education, health, social security and pension, agriculture, employment among others. The pursuit of concrete, self-interested, immediate gains presents a huge obstacle to political elites' institutional capacity to enact long term policies into enforceable laws. The capacity and the urge to plan and implement long term policies suffer institutional constraints from organized interest groups that seek to persuade and in most cases pressurize policy making in their favour. The question is why would the Government of Ghana preoccupy itself with long term development issues when there is an incessant pressure on it to deliver immediate group-pleasing goods? As Paehlke (1989:200) puts it "policies favour the most organized interest groups". In Ghana, the prominent space social groups enjoy usually feed them with extraordinary lobbying prowess to affect policy decisions in their advantage or even sometimes succeed in forcing a legislation as highlighted above. In his analysis of the GPRS I\&II plans for instance, Abu (2015) indicates that the plans could not survive the huge criticisms from CSOs culminating iin it being set aside in 2008. Abdulai and Quantson (2008) add that although CSOs were largely consulted and involved in the formulation of the GPRS II compared to the GPRS I, the former was made unpopular and largely kicked against for not adequately representing sufficient CSO interests.

To be sure, one can always expect organised groups to kick against policies that do not represent the specific interest of their members; a phenomenon that frustrates development. Another specific case is the fierce rejection of the 25 year energy sector restructuring policy of the NDC government in 2015 by several labour unions that were to be directly affected by the policy (Atarah, 2015). As a result of persistently inadequate power supply for many years, the economy of Ghana took a nosedive as small scale entrepreneurs like hairdressers, carpenters, tailors, and barbers began to face imminent bankruptcy. The government's planned response to restructure the Electricity Company of Ghana (ECG) which is a state-owned power distribution company to allow for private sector participation with the help from the Millennium Challenge Corporation - an aid agency of the US government - was jointly vehemently resisted by organised labour groups like the Public Utility Workers Union (PUWU) and the Public Service Workers Union (PSWU) and many other affected organizations (Asamoah, 2016). The implementation of this policy is presently in limbo. Long term policies like these usually suffer institutional constraints from interest groups that seek to persuade and in most cases pressurize policy making in their favour.

I should indicate however that not all organised groups stand in the way of long term policies. In fact some interest groups like environmental groups usually advocate for long term policies on climate change, for example. Therefore any generalization that interest groups are anti-long term due to their specific interests and their being 
short term costs sufferers of long term policies may be problematic. The point, however, is that the prominent space organised groups enjoy in Ghana's democracy and the specificities of their demands usually pitch them against long term policies that impose short term costs on their members especially in situations where the effect of the imposed long term policy will not be immediately visible as in the case of the above scenarios. This explains why successive governments quickly set aside development plans in pursuit of voter/group-pleasing policies to stay electorally appealing. Thus the imperatives of the "next election" and state-society pressure and agitations make Ghanaian political actors more short-sighted in their development choices. This paper argues that while democratic political elites may favour long term planning and policy investment, they are very calculative when embarking on them and may only do so when they are reasonably electorally safe and insulated from the competing demands of organised groups.

\section{Conclusion}

Democracy and development are interlinked and exhibit multiple patterns of connection. Adding long term policy planning to this mix further complicates the relationship. The study analysed this relationship by investigating the conditions under which democracies pursue long term plans in order to deliver development using Ghana as a case study. This was influenced by the twin theoretically opposing assumptions that democracy could either be a necessary ingredient for development or possess anti-long term policy investment capacity that ultimately frustrates development. I have shown that Ghana has made giant strides towards democratic consolidation. This has, however, not moved in tandem with development. I have shown that the structure of Ghana's economy has not sufficiently transformed since the country still operates on undiversified production base, weak manufacturing sector and so on. The many development plans which contained long term investment, transformation and industrialization programs to change the structure of the economy have, however, either been implemented in part or completely set aside by successive governments. In understanding why Ghana's democratic ruling elites abandon the implementation of long term plans which the paper highlighted as crucial for development, three fundamental factors were identified. These must be satisfied if democracies are to concentrate on policies that transcend their mandatory tenure of office.

Based on the empirical insight into Ghana's democracy and developmental trajectory, I have argued that democracies pursue long term policies when ruling elites enjoy maximum electoral safety or near insulation from political change and are under less pressure from CSOs to provide immediate goods. This finding, however, does not assume democratic political actors to be mechanistic and only strictly react to long term policies under these conditions. The paper argues that there could be long term policy investment when there is elite consensus among the relevant political actors and stakeholders that a proposed long term policy will deliver substantial net social returns. It is thus recommended that elite consensus takes centre-stage in the planning and implementation of long term policies in democracies. For democracies to embark on long term investments, there must be consensus among the relevant political elites and groups that the proposed policy investment will deliver substantial net long term social returns. Note that countries differ on their levels of democratic inclusiveness. Therefore, the success of a long term policy may be dependent on how inclusive and consensus driven the democratic institutional arrangement of the country in question is.

\section{REFERENCES}

Abdulai, G., \& Sithole, A. (2012). Ghana: A Beacon of Hope in Africa. Policy \& Practice Brief, Africa Centre for Constructive Resolution of Disputes, \#018 October 2012.

Sprinz, D. F. (2009). Long-Term Environmental Policy: Definition, Knowledge, Future Research. Global Environmental Politics, 9(3), 1-8. https://doi.org/10.1162/glep.2009.9.3.1

Stănculescu, M. (2003). Toward Country - Led Development. A Multi-Partner Evaluation of the Comprehensive Development Framework. Findings from Six Country Case Studies: Bolivia, Burkina, Faso, Ghana, Romania, Uganda, Vietnam, IBRD The World Bank, Washington, USA.

Stiglitz, J. E. (1996). SOME LESSONS FROM THE EAST ASIAN MIRACLE. The World Bank Research Observer, 11(2), 151-177. https://doi.org/10.1093/wbro/11.2.151

Tandoh-Offin, P. (2013). Development Planning in Ghana Since 1992: Implications for the Decentralization Process. International Relations and Diplomacy, 1(2), 93-107.

Thompson, D. F. (2005). Democracy in Time: Popular Sovereignty and Temporal Representation. Constellations, 12(2), 245-261. https://doi.org/10.1111/j.1351-0487.2005.00414.x

Thompson, D. F. (2010a). Representing future generations: Political presentism and democratic trusteeship. Critical Review of International Social and Political Philosophy, 13(1), 17-37. https://doi.org/10.1080/13698230903326232

Thompson, D. F. (2010b). Representing future generations: Political presentism and democratic trusteeship. Critical Review of International Social and Political Philosophy, 13(1), 17-37. https://doi.org/10.1080/13698230903326232 
Whitfield, L. (2009). Change for a Better Ghana: Party Competition, Institutionalization and Alternation in Ghana's 2008 Elections. Journal of African Affairs, 108, 621-641.

World Bank. (2004). Natural visions matter: Lessons of success. Proceedings of public-private sector development forum, Santiago, Chile, July 25-27, 2004.

World Bank. (2020). The World Bank in Ghana: Overview. World Bank in Ghana. https://www.worldbank.org/en/country/ghana/overview\#1 (Accessed 15.08.2021)

Zysman, J. (1983). Governments, markets, and growth: Financial systems and the politics of industrial change (4. print). Cornell Univ. Press. 